\title{
Evaluation of MODIS-Aqua and OLCI Chlorophyll-a products in contrasting waters of the Southwestern Atlantic Ocean
}

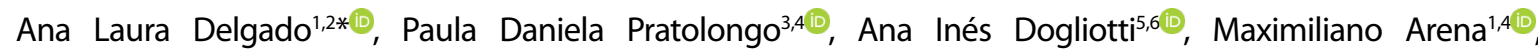 \\ Carla Celleri ${ }^{30}$, John Edison Garzón Cardona ${ }^{10}$, Ana Martinez ${ }^{7,8}$
}

\begin{abstract}
${ }^{1}$ Instituto Argentino de Oceanografía (IADO), Consejo Nacional de Investigaciones Científicas y Técnicas - Universidad Nacional del Sur (CONICET-UNS), (Camino La Carrindanga km 7, Bahía Blanca (8000), Argentina).

2 Departamento de Geografía y Turismo, Universidad Nacional del Sur (UNS), (12 de Octubre y San Juan, Bahía Blanca (8000), Argentina):

${ }^{3}$ Centro de Recursos Naturales Renovables de la Zona Semiárida (CERZOS), Consejo Nacional de Investigaciones Científicas y Técnicas - Universidad Nacional del Sur (CONICET-UNS), (Camino La Carrindanga km 7, Bahía Blanca (8000), Argentina).

${ }^{4}$ Departamento de Biología, Bioquímica y Farmacia, Universidad Nacional del Sur (UNS), (San Juan 670, Bahía Blanca (8000), Argentina).

${ }^{5}$ Instituto de Astronomía y Física del Espacio (IAFE), Universidad de Buenos Aires, Facultad de Ciencias Exactas y Naturales, Buenos Aires, Argentina (CONICET -UBA), (Ciudad Universitaria (C1428ZAA), (Buenos Aires, Argentina)).

${ }^{6}$ Instituto Franco-Argentino para el Estudio del Clima y sus Impactos (UMI IFAECI/CNRS-CONICET-UBA), (Ciudad Universitaria (C1428EGA), (Buenos Aires, Argentina)).

${ }^{7}$ Departamento de Química, Universidad Nacional del Sur (UNS), (San Juan 670, Bahía Blanca (8000), Argentina).

${ }^{8}$ Instituto de Química del Sur (INQUISUR), Consejo Nacional de Investigaciones Científicas y Técnicas - Universidad Nacional del Sur (CONICET-UNS), (San Juan 670, Bahía Blanca (8000), Argentina).
\end{abstract}

* Corresponding author: aldelgado@iado-conicet.gob.ar

Satellite chlorophyll-a concentration (Chl-a) estimations provide a valuable tool to study marine phytoplankton dynamics with unprecedented spatial and temporal coverage. Standard empirical Chl-a algorithms perform well where phytoplankton is the dominant optically active component in seawater, but usually fail in those regions where there is a high optical influence from multiple dissolved and particulate components that are not covariant with Chl-a (Prieur and Sathyendrenath, 1981). Therefore, in coastal regions, where colored dissolved and suspended particulate matter are dominant, it is crucial to perform an accuracy assessment of satellite Chl-a products to ensure their reliable use.

The water masses on the Northern Patagonian continental shelf (Figure 1) have sub-Antarctic

Submitted on: 20-August-2020

Approved on: 30-November-2020

Associate Editor: Carmen G. Castro

() 2021 The authors. This is an open access article distributed under the terms of the Creative Commons license. origin, mixed with regional coastal inputs, and are influenced by the temperate thermal cycle and NW prevailing winds, making this region a complex oceanographic and ecological system (Lucas et al., 2005). Its coastal zone presents temperate $\left(15^{\circ} \mathrm{C}\right)$, high saline $(35)$ and turbid waters (35 NTU) with pronounced seasonal variability (Delgado et al., 2017). The Bahia Blanca Estuary is a tidally dominated, turbid and mixed system that is a main source of fine sediment to the inner shelf (Menendez et al., 2016) towards the eastern coastline (Delgado et al., 2017). Phytoplankton is mainly dominated by diatoms, comprising more than the $50 \%$ of the cell abundances and biomass, followed by dinoflagellates (Guinder et al., 2018) and coccolithophores, both also highly abundant (Guinder et al., 2018; Delgado et al., 2019).

Long term field studies are quite scarce in the Argentine Sea, given the limited financial resources for oceanographic research, emphasizing the relevance of reliable $\mathrm{Chl}-\mathrm{a}$ estimations derived 


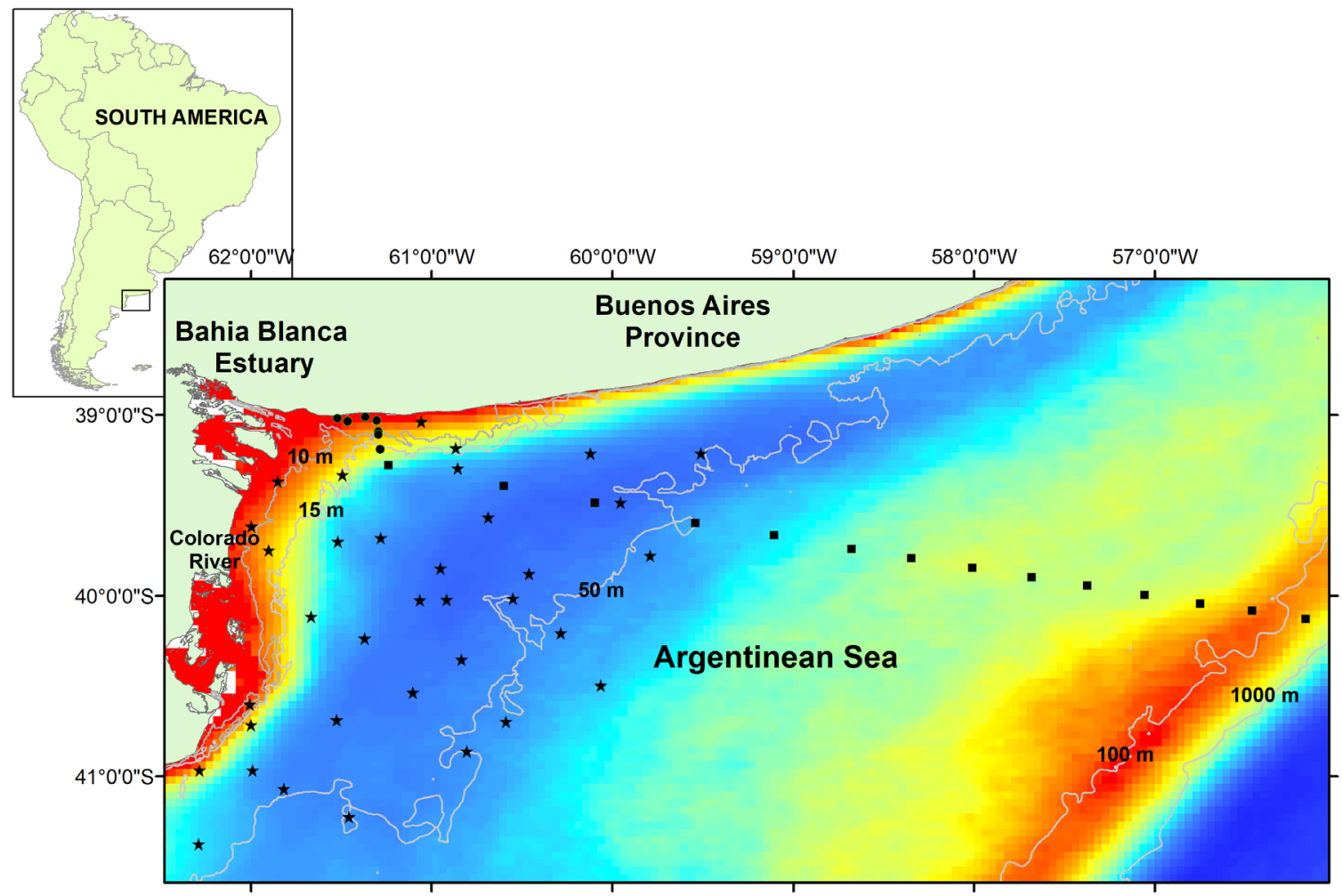

Figure 1. Location of study area in the northern Patagonian continental shelf and sampling sites. Black circles indicate sites sampled in the coastal area $(\mathrm{z}<15 \mathrm{~m}, \mathrm{~N}=28)$ collected between November 2013 and March 2017. Black stars are stations collected from the R/V Dr. Bernardo Houssay and ARA Puerto Deseado ( $N=49$ ) in October 2010, April 2012, April 2013 and black squares are sites collected in March 2019 on the PNA Dr. Bernardo Houssay $(\mathrm{N}=16)$.

from satellite data. Therefore, the objective of the present study is to test, for the first time in this optically complex area, using multiple atmospheric corrections and algorithms, several different Chl-a products derived from the Moderate Resolution Imaging Spectroradiometer on board Aqua (MODISAqua) and the Ocean and Land Color Instrument on board Sentinel 3 (OLCl-Sentinel 3) using in situ Chl-a.

Sampling was performed either from fishing boats or during dedicated oceanographic cruises, collecting a total of 93 surface samples. From November 2013 to March 2017, 28 samples were collected in the permanent sampling area located in the coastal zone $\left(39^{\circ} \mathrm{S}-62.5^{\circ} \mathrm{W} ; 41.5^{\circ} \mathrm{S}-60^{\circ} \mathrm{W}\right)$ from local artisanal fishing boats (red dots in Figure 1). During four oceanographic cruises, 65 samples were collected in October 2010, April 2012, April 2013 and March 2019 from the R/V Dr. Bernardo Houssay and ARA Puerto Deseado on the continental shelf (Figure 1, black and green stars). Field Chl-a was estimated after filtering between 100 and $200 \mathrm{ml}$ of seawater through Whatman GF/F filters, depending on water turbidity. Immediately after filtration, the filters were wrapped in aluminum foil and stored in an ultra-low freezer at $-80{ }^{\circ} \mathrm{C}$ until laboratory analysis. Photosynthetic pigments were extracted with $90 \%$ acetone for 24 $\mathrm{h}$ in the darkness at $-20^{\circ} \mathrm{C}$. Chl-a was determined by fluorimetry after Holm-Hansen et. al (1965) with a Shimadzu RF-5301 spectrofluorophotometer using the excitation and emission bands centered at 460 and $671 \mathrm{~nm}$, respectively.

Daily MODIS-Aqua level $1 \mathrm{~A}$ data at $1.1 \mathrm{~km}$ spatial resolution for the sampling dates were downloaded from the Ocean Color web site (http://oceancolor. gsfc.nasa.gov) and were processed using SeaDAS 7.4 software to obtain L2 Chl-a product using the OC3M algorithm (O'Reilly et al., 2000) and a switching atmospheric correction (AC) algorithm that uses the 
near infrared (NIR) or the short-wave infrared (SWIR) bands (NIR/SWIR-OC3M). Following the good results obtained by Delgado et al. (2019) in this study area, the NASA standard AC algorithm that uses NIR bands (Stumpf et al., 2003; Bailey et al., 2010) was applied to stations located offshore ( $>10 \mathrm{~km}$ from the coast), while the alternative $A C$ algorithm that uses SWIR bands was applied to pixels located less than $10 \mathrm{~km}$ from the coast (Wang and Shi, 2005). Given the presence of turbid waters in the region, the high total radiance mask (HILT) was not applied and the cloud-masking was performed using the Rayleigh-corrected reflectance (dimensionless) at $2130 \mathrm{~nm}$ with a threshold of 0.018 .

Daily OLCl-Sentinel $3 \mathrm{~A}$ and B level 2 (L2-WFR) images for the sampling dates at $300 \mathrm{~m}$ spatial resolution were downloaded from the Eumesat web page (https://coda.eumetsat.int/) and the chl_OC4Me and chl_nn Chl-a products were evaluated. The chl_OC4Me product, developed for Case-1 waters, is calculated using a combination of the baseline and the bright pixel (Antoine and Morel, 1999, Moore et al. 1999) atmospheric correction combination (BAC/BPAC) and the Chl-a semi-analytical maximum band ratio OC4Me algorithm, originally designed for the MERIS sensor (Morel et al., 2007). The chl_nn alternative product for Case- 2 waters is calculated using an alternative $A C$ developed for complex waters (AAC) based on an artificial neural network (Doerffer and Schiller, 2007) from which Chl-a concentration is derived through an Inverse Modelling Technique.

The match-up procedure consisted of extracting a box of $3 \times 3$ pixels centered at the location of the in situ measurements. A match-up was accepted only if more than 6 out of 9 pixels of the box were valid considering the standard flags. Then, a spatial uniformity criterion was applied based on the coefficient of variation (cv), the ratio of the standard deviation to the mean pixel value of the box, where match-ups with $\mathrm{cv}>0.3$ were discarded. A time difference window of $\pm 6 \mathrm{~h}$ between the satellite overpass and the in situ measurements was considered for the mid-shelf region (not influenced by tidal forces), while for coastal stations $(<10 \mathrm{~km}$ from the coast) a time difference window of $\pm 2 \mathrm{~h}$ was used to avoid the possible influence of the tide.

To compare the performance of the different $\mathrm{Chl}-\mathrm{a}$ products, linear regressions were performed; the slope, intercept, and coefficient of determination $\left(R^{2}\right)$ were computed on log-transformed satellite and in situ Chl-a data, because bio-optical data is known to have a log-normal distribution (Campbell et al., 1995). After analysis, the results were back transformed to linear space for interpretation (Seegers et al., 2018). The statistical errors considered were the root-meansquare error (RMSE) (Equation 1), bias (Equation 2), and the percentage error (PE) (Equation 3), defined as follows:

$$
\begin{aligned}
& R M S E=10^{\sqrt{\frac{1}{n}} \sum[\log y-\log x]^{2}} \\
& \text { bias }=10^{\frac{1}{n}} \sum(\log y-\log x) \\
& P E=\frac{1}{n} \sum(|y-x|) * 100
\end{aligned}
$$

where $x$ is the in situ measured value, $y$ the satellite estimated value and $\mathrm{n}$ the number of match-ups.

For the analyzed period measured, Chl-a values varied between 0.22 and $7.03 \mathrm{mg} \mathrm{m}^{-3}$ with a mean value of $1.64 \mathrm{mg} \mathrm{m}^{-3}$. From the total of 93 samples collected for the whole study area, only 41 remained as valid match-ups after applying the exclusion criteria previously described. Considering all matchups $(\mathrm{N}=41)$, the MODIS-Aqua NIR/SWIR-OC3M product showed a poor correlation with in situ data $\left(R^{2}=0.39\right.$; black line and equation in Figure $\left.2 A\right)$. Even though the slope is close to 1 , large errors indicate a poor performance of the algorithm with high scatter $(\mathrm{RMSE}=1.65, \mathrm{PE}=118 \%)$ and a clear tendency to overestimate in situ data, as indicated by the bias (1.18). This result is expected as more than half of the samples were collected within the coastal zone $\left(z<15 \mathrm{~m} ; \mathrm{N}=23 ; \mathrm{R}^{2}=0.21\right.$, red symbols in Figure $\left.2 \mathrm{~A}\right)$, characterized by turbid waters (Delgado et al., 2017; 2019), where Chl-a empirical algorithms usually tend to fail (O'Reilly et al., 2000). Within this coastal zone (z $<15 \mathrm{~m}$ ), SPM concentrations varied between 30-100 $\mathrm{mgl}^{-1}$ (Delgado et al. 2019) and the composition of the phytoplankton community was highly variable. It was dominated by large chain-forming diatoms (40-80\% of total abundance), with a relatively low specific absorption coefficient (mean $0.032 \mathrm{(m}^{2} \mathrm{mg}$ $(\mathrm{Chl}-\mathrm{a})^{-1}$ ) due to the packaging effect (Delgado et al., 2019). This zone is also characterized by the regular presence of coccolitophorid species Gephyrocapsa oceanica (Delgado et al.,2019., Guinder et al., 2018), 

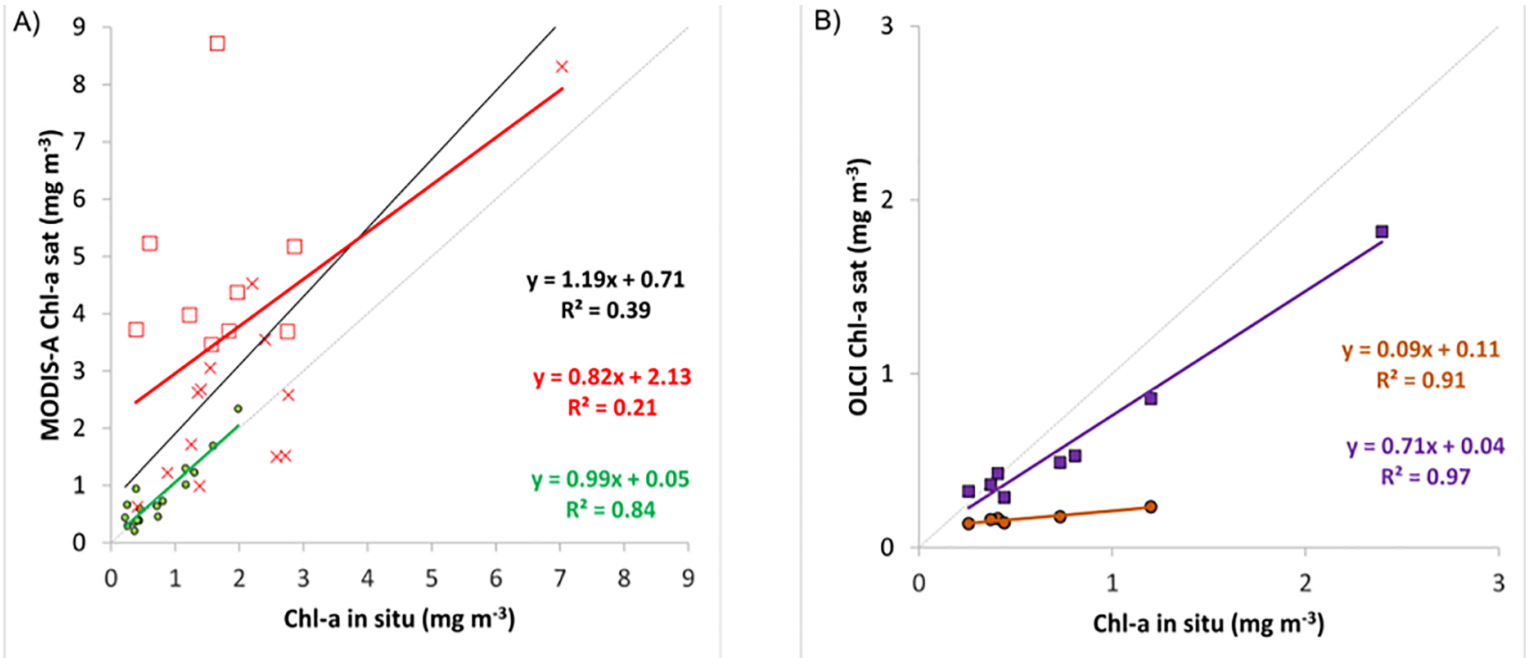

Figure 2. Comparison between in situ and satellite-derived Chl-a on the Northern Patagonian continental shelf. A) MODIS-Aqua NIR/SWIROC3M product linear regression considering all data (black line and equation); Color coded symbols indicate stations located deeper than 15 $\mathrm{m}$ depth (green) and coastal stations (red). For the coastal stations, squares indicate stations located less than $10 \mathrm{~km}$ from the coast (SWIR AC). Crosses indicate stations located $>10 \mathrm{~km}$ from the coast (NIR AC). B) OLCI-Sentinel 3 Chl-a chl_nn (orange) and chl_OC4Me (purple) products at offshore stations $(>15 \mathrm{~m})$. The coefficient of determination $\left(R^{2}\right)$ is shown.

which could cause high back-scattering on satellite imagery due to their calcified cell structure (Brown and Yoder, 1994). In turn, when only stations located offshore from the $15 \mathrm{~m}$ isobath were considered, the OC $3 \mathrm{M}$ algorithm showed the best performance (Figure $2 \mathrm{~A}$ green symbols). For these stations, waters have typically lower SPM concentrations $(<6 \mathrm{mg}$ $\mathrm{I}^{-1}$; Delgado et al., 2019) and low CDOM absorption values (443) (0.06 - $0.13 \mathrm{~m}^{-1}$; unpublished results Maximiliano Arena). Phytoplankton communities in these stations were dominated by dinoflagellates, smaller cells corresponding to the nanoplankton size class (Guinder et al., 2018). In the offshore waters, match-ups showed a better fit $\left(R^{2}=0.84\right)$ and lower errors (bias $=1.09$ and $\mathrm{PE}=16 \%$ ) than those observed in the coastal zone alone or for all the data pooled together (Figure 2A, Table1), with estimates closer to the 1:1 line. The AC performance could not be evaluated at this study due to the lack of radiometric measurements; nevertheless, based on previous results (Delgado et al., 2019), showing good performances in offshore waters and high errors in coastal waters (disregarding the bands used for the AC: NIR or SWIR), we can infer that AC is not a major issue. On the other hand, high SPM values, variations in pigment packaging, species composition, and variable CDOM concentrations (not reported here) relative to phytoplankton biomass, seem to be the main causes of the poor performance of $\mathrm{Chl}$-a estimation in the near-coastal area using the standard empirical algorithm leading to a general overestimation of the measured $\mathrm{Chl}$-a.

Sentinel 3 images are available since November 2017, thus OLCl derived Chl-a products were only tested using in situ Chl-a determinations obtained during the oceanographic cruise on board the R/V Dr. Bernardo Houssay in March 2019 with offshore data (z $>15 \mathrm{~m}$, Figure 1, green stars). The Case-2 water neural network Chl-a product (chl_nn) rendered a good fit $\left(R^{2}=0.91\right)$ and low scatter around the regression line, but it largely underestimated $\mathrm{Chl}-\mathrm{a}$ values (PE $=39$ $\%)$, not representing well the measured $\mathrm{Chl}$-a range (Figure 2B, orange). In turn, the standard Case-1 water OLCl OC4Me product presented the best fit $\left(R^{2}=0.97\right)$ and the lowest errors $(P E=21 \%)$, with predicted values closer to the 1:1 line (Figure $2 \mathrm{~B}$, purple). A slight underestimation of the in situ data can be observed, which may result from the reported tendency of $\mathrm{OLCI} L 2$ products to underestimate the water-leaving radiance (Zibordi et al., 2018).

It can be concluded that the standard MODIS-Aqua (OC3M) and $\mathrm{OLCl}(\mathrm{OC} 4 \mathrm{Me})$ Case- 1 waters products are reliable in the inner shelf and mid-shelf ( $z>15 \mathrm{~m}$ ) of the Southwestern Buenos Aires Province (Figure 1). 
Table 1. Statistical results of the performance of MODIS-Aqua and OLCI-Sentinel $3 \mathrm{Chl}$-a products evaluated on the northern Patagonian Shelf. $\mathrm{R}^{2}=$ coefficient of determination; $\mathrm{RMSE}=$ root mean square error; $\mathrm{PE}=$ percentage error; $\mathrm{N}$ $=$ number of match ups; $z=$ depth $(m)$.

\begin{tabular}{|c|c|c|c|c|c|}
\hline \multirow{2}{*}{\multicolumn{4}{|c|}{$\begin{array}{c}\text { MODIS-Aqua } \\
\text { NIR/SWIR-OC3M }\end{array}$}} & \multicolumn{2}{|c|}{ OLCI-Sentinel 3} \\
\hline & & & & \multirow{2}{*}{$\begin{array}{l}\text { chl_nn } \\
z>15\end{array}$} & \multirow{2}{*}{$\begin{array}{c}\text { chl_OC4Me } \\
\quad \mathrm{z}>15\end{array}$} \\
\hline Depth (m) & All data & $z<15$ & $z>15$ & & \\
\hline $\mathrm{R}^{2}$ & 0.39 & 0.21 & 0.84 & 0.91 & 0.97 \\
\hline Slope & 1.19 & 2.13 & 0.99 & 0.097 & 0.71 \\
\hline Intercept & 0.71 & 0.82 & 0.05 & 0.11 & 0.04 \\
\hline bias & 1.18 & 1.52 & 1.09 & 0.39 & 0.8 \\
\hline RMSE & 1.65 & 2.31 & 1.51 & 3.14 & 1.36 \\
\hline PE (\%) & 118 & 203 & 16 & 39 & 21 \\
\hline $\mathrm{N}$ & 41 & 23 & 18 & 6 & 8 \\
\hline
\end{tabular}

Environmental or monitoring studies can be performed considering this highly valuable data with confidence knowing there is only a slight underestimation of $\mathrm{Chl}-\mathrm{a}$ in situ values for concentrations above $1 \mathrm{mg} \mathrm{m}^{-3}$. For the coastal zone located in shallow waters $(\mathrm{z}<15 \mathrm{~m})$, the Case- 1 water MODIS-Aqua OC3M Chl-a product completely fails to reproduce the in situ fluorometric $\mathrm{Chl}-\mathrm{a}\left(\mathrm{mg} \mathrm{m}^{-3}\right)$ values, evidence of the need to develop specific algorithms in these turbid and optically complex waters.

\section{ACKNOWLEDGMENTS}

The authors would like to thank the Consejo Nacional de Investigaciones Cientificas y Tecnicas (CONICET) for their financial support. This research was done in the frame of PICT-2016-0817 and PICT-2014-0445 projects founded by the Agencia de Promoción Científica y Tecnológica. We specially thank the Camara de Pescadores Artesanales de Monte Hermoso y Pehuén Co (Eduardo Flores and Juancito) for their invaluable help. We also thank the Ocean Color NASA group for the distribution of MODIS-Aqua data and Eumesat for the distribution of Sentinel-3 data. Finally, we are grateful to the anonymous reviewers who improved the quality of the note.

\section{AUTHOR CONTRIBUTIONS}

AA.L.D.: Conceptualization; Investigation; Writing original draft; Writing - review \& editing.

P.D.P: Funding Acquisition; Writing - review \& editing.

A.D.: Conceptualization; Writing - review \& editing.

M.A.: Investigation; Writing - review \& editing.
C.C.: Writing - review \& editing.

J.E.G.C.: Investigation; Writing - review \& editing.

A.M.: Investigation; Writing - review \& editing.

\section{REFERENCES}

ANTOINE, D. \& MOREL, A. 1999. A multiple scattering algorithm for atmospheric correction of remotely sensed ocean colour (MERIS instrument): principle and implementation for atmospheres carrying various aerosols including absorbing ones. International Journal of Remote Sensing, 20(9), 18751916.

BAILEY, S. W., FRANZ, B. A. \& WERDELL, P. J. 2010. Estimation of near-infrared water-leaving reflectance for satellite ocean color data processing. Optics Express, 18(7), 7521-7527.

BROWN, C. W. \& YODER, J. A. 1994. Distribution pattern of coccolithophorid blooms in the western North Atlantic Ocean. Continental Shelf Research, 14(-32), 175-197.

CAMPBELL, J. W. 1995. The lognormal distribution as a model for bio-optical variability in the sea. Journal of Geophysical Research, 100(C7), 13237-13254.

DELGADO, A. L., GUINDER, V. A., DOGLIOTTI, A. I., ZAPPERI, G. \& PRATOLONGO P. 2019. Validation of MODIS-Aqua bio-optical algorithms for phytoplankton absorption coefficient measurement in optically complex waters of El Rincón (Argentina). Continental Shelf Research, 173, 73-86.

DELGADO, A. L., MENÉNDEZ, M. C., PICCOLO, M. C. \& PERILLO, G. M. E. 2017. Hydrography of the inner continental shelf along the southwest Buenos Aires Province, Argentina: influence of an estuarine plume on coastal waters. Journal of Coastal Research, 33(4), 907-916.

DOERFFER, R. \& SCHILLER, H. 2007. The MERIS Case 2 water algorithm. International Journal of Remote Sensing, 28(3-4), 517-535.

GUINDER, V. A., TILLMANN, U., KROCK, B., DELGADO, A. L., KROHN, T., CARDONA, J. E. G., METFIES, K., ABBATE, C. L., SILVA, R. \& LARA, R. 2018. Plankton multiproxy analyses in the Northern Patagonian Shelf, Argentina: Community structure, phycotoxins, and characterization of toxic Alexandrium strains. Frontiers in Marine Science, 5, 394. 
HOLM-HANSEN, O, LORENZEN, C. J, HOLMES, R. W. \& STRICKLAND, J. D. H. 1965. Fluorometric determination of chlorophyll. Journal of Marine Science, 30(1), 3-15.

LUCAS, A. J., GUERRERO, R. A., MIANZÁN, H. W., ACHA, E. M. \& LASTA, C. A. 2005. Coastal oceanographic regimes of the northern Argentine continental shelf (34-43 degrees S). Estuarine, Coastal and Shelf Science, 65(3), 405-420.

MENÉNDEZ, M. C., DELGADO, A. L., BERASATEGUI, A. A., PICCOLO, M. C. \& HOFFMEYER, M. S. 2016. Seasonal and tidal dynamics of water temperature, salinity, chlorophyll-a, suspended particulate matter, particulate organic matter, and zooplankton abundance in a shallow, mixed estuary (Bahía Blanca, Argentina). Journal of Coastal Research, 32(5), 1051-1061.

MOORE, G. F., AIKEN J. \& LAVENDER, S. J. 1999. The atmospheric correction of water colour and the quantitative retrieval of suspended particulate matter in Case II waters: application to MERIS. International Journal of Remote Sensing, 20(9), 1713-1733.

MOREL, A., HUOT, Y., GENTILI, B., WERDELL, P. J., HOOKER, S. B. \& FRANZ, B. A. 2007. Examining the consistency of products derived from various ocean color sensors in open ocean (case 1) waters in the perspective of a multi-sensor approach. Remote Sensing of Environment, 111(1), 69-88.

O'REILLY, J. E., MARITORENA, S., SIEGEL, D. \& O'BRIEN, M. C. 2000. Ocean color chlorophyll-a algorithms for SeaWiFS, OC2, and OC4: version 4. In: HOOKER, S. B. \& FIRESTONE, E. R. (eds.). SeaWiFS postlaunch technical report series, volume 11: SeaWiFS postlaunch calibration and validation analyses, part 3. Greenbelt: NASA Goddard Space Flight Center.
PRIEUR, L. \& SATHYENDRANATH, S. 1981. An optical classification of coastal and oceanic waters based on the specific spectral absorption curves of phytoplankton pigments, dissolved organic matter, and other particular materials. Limnology and Oceanography, 26(4), 671-689.

SEEGERS, B. N., STUMPF, R. P., SCHAEFFER, B. A., LOFTIN, K. A. \& WERDELL, P. J. 2018. Performance metrics for the assessment of satellite data products: an ocean color case study. Optics Express, 26(6), 7404-7422.

STUMPF, R. P., ARONE, R. A., GOULD, R. W. \& RANSIBRAHMANAKUL, V. 2003. A partially coupled ocean-atmosphere model for retrieval of water-leaving radiance from SeaWiFS in coastal waters. In: HOOKER, S. B. \& FIRESTONE, E. R. (eds.). SeaWiFS postlaunch technical report series. Greenbelt: NASA Goddard Space Flight Space Center.

VOLPE, G., SANTOLERI, R., VELLUCCI, V., D'ALCALA, M. R., MARULLO, S. \& D'ORTENZIO, F. 2007. The colour of the Mediterranean Sea: global versus regional bio-optical algorithms evaluation and implication for satellite chlorophyll estimates. Remote Sensing of Environment, 107(4), 625-638.

WANG, M. \& SHI, W. 2005. Estimation of ocean contribution at the MODIS near-infrared wavelengths along the east coast of the U.S.: two case studies. Geophysical Research Letters, 32(13), L13606.

ZIBORDI, G., MÉLIN, F. \& BERTHON, J. F. 2018. A regional assessment of $\mathrm{OLCl}$ data products. IEE Geoscience and Remote Sensing Letters, 15(10), 1490-1494. 